\title{
RANCANGAN PERBAIKAN PENILAIAN TUTORIAL BERDASARKAN SUDUT PANDANG TUTOR DAN MAHASISWA SERTA LITERATUR
}

\author{
Fuad Khadafianto*, Gandes Retno Rahayu**, Efrayim Suryadi** \\ * Medical Education Unit, Fakultas Kedokteran Universitas Islam Indonesia \\ ** Departemen Pendidikan Kedokteran, Fakultas Kedokteran Universitas Gadjah Mada
}

\begin{abstract}
Background: Problem Based Learning (PBL), a form of active learning model that is constructive, independent, collaborative and contextual, implemented in the learning process in the form of tutorial discussions. The quality of tutorial discussion need to be improved. One way to improve the quality of the tutorial is to revise or to select the appropriate assessment methods of tutorial discussion. Aside from tutor perception as a user, student perception about the benefits of the assessment process in PBL as subjects assessed need to be considered as a consideration in determining the appropriate model of assessment. One of tutorial discussion PBL method is using a seven jumps. This tutorial process is assessed and the result becomes a component of summative assessment. Therefore, the quality of these assessments must be guaranteed in terms of validity, reliability, impact of learning and in terms of ease of implementation.

Method: This study used a qualitative method through a case study approach that use focus group discussions and in-depth interviews. This research carried out in the faculty of medicine of Islamic University of Indonesia. The study population was representative students of the years 2011-2014, the representative of tutors, and the leadership of the study program and faculty.

Results: there were eight categories of perception in the tutorial discussion assessment. The perceptions included the perception of tutor and student knowledge about the assessment tutorials, the conformity tutorial discussion assessment with the concept of PBL, the technical assessment, the deviation judgment, the assessment objectivity, the assessment impact of the tutorial process, the learning/educational impact of tutorials assessment, and the recommendation of tutorial assessment

Conclusion: Based on eight categories of perception in the tutorial discussion assessment, this study recommended three things, recommendation to keep doing the assessment of tutorial, to improve the objectivity of ratings tutorial by improving various components related to the assessment of tutorials, and to prevent the occurrence of irregularities in tutorial assessment.
\end{abstract}

Keywords: problem based learning, tutorials assessment, tutor perception, student perception

\section{ABSTRAK}

Latar belakang: Model Problem based learning (PBL), bentuk pembelajaran model belajar aktif yang bersifat konstruktif, mandiri, kolaboratif dan kontekstual. Implementasi PBL dalam proses belajar mengajar diwujudkan dalam bentuk diskusi tutorial. Salah satu cara meningkatkan kualitas proses tutorial yaitu dengan memperbaiki atau memilih metode penilaian tutorial yang tepat. Selain persepsi tutor sebagai pengguna, persepsi mahasiswa mengenai manfaat dilaksanakannya suatu proses penilaian dalam PBL sebagai subjek yang dinilai perlu diperhatikan sebagai pertimbangan dalam menetapkan model penilaian yang dilakukan.

korespondensi: f_khadafi_meu@yahoo.com 
Metode diskusi tutorial-PBL yang dapat digunakan salah satunya adalah menggunakan seven jumps. Penilaian proses tutorial menjadi komponen dari penilaian yang bersifat sumatif, untuk itu penilaian ini harus dijamin kualitasnya baik dari segi validitas, reliabilitas, dampak pembelajarannya maupun dari segi kemudahan pelaksanaannya.

Metode: Penelitian ini menggunakan metode kualitatif melalui pendekatan studi kasus dengan menggunakan FGD dan in-depth interview. Penelitian ini dilakukan di program studi pendidikan dokter fakultas kedokteran Universitas Islam Indonesia. Populasi penelitiannya adalah perwakilan mahasiswa dari angkatan 2011-2014 dan perwakilan tutor dan pimpinan fakultas/program studi.

Hasil: Terdapat 8 (delapan) kategori persepsi yaitu persepsi pengetahuan tutor dan mahasiswa terhadap penilaian tutorial, kesesuaian penilaian tutorial dengan konsep PBL, teknis penilaian, penyimpangan penilaian, objektifitas penilaian, dampak penilaian terhadap proses tutorial, learning/educational impact penilaian tutorial, dan usulan penilaian tutorial

Kesimpulan: Dari 8 (delapan) kategori persepsi penelitian ini merekomendasikan 3 (tiga) hal yaitu pertama pelaksanaan penilaian tutorial diharapkan tetap dilakukan, peningkatan objektifitas penilaian tutorial melalui perbaikan berbagai komponen yang terkait penilaian tutorial dan perlu dilakukan upaya pencegahan terjadinya penyimpangan penilaian tutorial.

Kata kunci: problem based learning, penilaian tutorial, persepsi tutor, persepsi mahasiswa.

\section{PENDAHULUAN}

Problem based learning (PBL) adalah suatu metode pembelajaran dalam bentuk kelompok kecil berbasis masalah dimana sekelompok pembelajar dan fasilitator berdasarkan masalah berkolaborasi untuk mengidentifikasi tujuan dan kebutuhan belajar yang diikuti dengan belajar mandiri, menerima masukan dan menarik kesimpulan berdasarkan kesepakatan kelompok. ${ }^{1}$

Pada model PBL, bentuk pembelajaran bergeser menjadi model belajar aktif yang bersifat konstruktif, mandiri, kolaboratif dan kontekstual yang diimplementasikan dalam bentuk diskusi tutorial. Salah satu cara meningkatkan kualitas proses tutorial adalah dengan memperbaiki atau memilih metode penilaian tutorial yang tepat.

Pemilihan metode penilaian tutorial yang tepat tidak bisa diseragamkan antara satu institusi pendidikan yang satu dengan yang lainnya, bahkan antara suatu negara yang satu dengan negara lainnya karena banyak hal yang harus diperhatikan, jika ingin mengadopsi pola penilaian tutorial tertentu dari institusi atau dari negara lain maka proses adaptasi/penyesuaian perlu dilakukan. Salah satu panduan memutuskan metode/alat ukur apa yang tepat digunakan yaitu: 1) jelas apa target yang akan dinilai, 2) teknik penilaian yang dipilih sesuai dengan target pembelajaran, 3) teknik penilaiaan yang dipilih melayani kebutuhan mahasiswa, 4) bila memungkinkan, menggunakan beragam indikator performa untuk tiap target pembelajaran, 5) ketika menginterpretasikan hasil penilaian mempertimbangkan keterbatasan mahasiswa. $^{2}$

Persepsi mahasiswa mengenai manfaat dilaksanakannya suatu proses penilaian dalam $\mathrm{PBL}$ sebagai subjek yang dinilai perlu diperhatikan sebagai pertimbangan dalam menetapkan model penilaian yang dilakukan. ${ }^{3}$

Diskusi tutorial merupakan gabungan dari aktifitas/ perilaku berkomunikasi dalam kelompok kecil dan kemampuan/pemahaman terhadap penguasaan ilmu. Terkait hal ini maka ada dua pilihan penilaiannya yaitu penilaian yang bersifat formatif berupa pemberian konstruktif feedback dan ada yang bersifat sumatif dapat berupa check list, rating scale, maupun rubric. Sedangkan dari segi siapa yang melakukan penilaian, diskusi tutorial dapat dinilai oleh tutor, self assessment maupun peer assessment. Dari segi waktu penilaian diskusi tutorial ada yang melakukan penilaian disetiap proses tutorial, ada yang digabungkan beberapa diskusi tutorial namun terkait problem yang sama dalam satu penilaian, 
dan ada yang dilakukan secara keseluruhan diakhir proses blok.

Institusi Pendidikan Dokter yang menggunakan kurikulum berbasis kompetensi (KBK) disertai model pembelajaran dengan pendekatan problem based learning (PBL). Konsekuensi dari metode ini adalah diskusi tutorial menjadi bagian utama dalam proses belajar-mengajar.

Salah satu metode pembelajaran tutorial yang dapat digunakan adalah menggunakan seven jumps. Program Studi Pendidikan Dokter Fakultas Kedokteran Universitas islam Indonesia (PSPD FK UII) sebagai salah satu contoh institusi yang menerapkan model pembelajaran ini, melakukan penerapan pembelajaran berupa tiap 1 skenario dilakukan 2-3 kali diskusi tutorial dengan durasi tiap tutorial selama 100 menit. Setiap proses diskusi tutorial terdiri dari 8-12 mahasiswa yang didampingi oleh seorang tutor. Pada prosesnya mahasiswa akan mendapatkan peran sebagai ketua diskusi, sekretaris dan anggota. Sedangkan tutor berperan sebagai fasilitator diskusi dan juga berperan sebagai evaluator jalannya proses diskusi tutorial.

Penilaian proses tutorial dilakukan disetiap pertemuan tutorial dan setiap tutor difasilitasi dengan sebuah lembar penilaian, yang berisi 5 aspek yang penilaian yaitu 1) sikap dan tanggung jawab, 2) peran aktif dan komunikasi, 3) jenis sumber informasi yang digunakan, 4) menguasai informasi yang disampaikan, 5) berpikir kritis. Masing-masing aspek penilaian tersebut memiliki rentang nilai bervariasi namun di dalam rentang 0 sampai dengan 3 yang disertai panduan penilaian dengan total jumlah nilai maksimal secara keseluruhan adalah 10 dan minimal 0 .

Penilaian proses tutorial ini merupakan salah satu bagian dari beberapa komponen penilaian yang bersifat sumatif dan memberikan persentase kontribusi bagi nilai akhir mahasiswa. Nilai tutorial memiliki 2 komponen yaitu 50\% nilai proses tutorial dan $50 \%$ nilai minikuis. Nilai tutorial memberikan kontribusi persentase sebesar 25-35\% dari nilai akhir.

Untuk menjaga kualitas pendidikan dokter, berbagai macam metode penilaian diskusi tutorial perlu dilihat apakah penilaian tersebut relevan dilakukan baik dari sudut pandang tutor maupun dari sudut pandang mahasiswa.

Proses penilaian tutorial jika menjadi komponen dari penilaian yang bersifat sumatif, harus dijamin kualitasnya baik dari segi validitas, reliabilitas, dampak pembelajaran maupun kemudahan pelaksanaannya. Untuk itu diperlukan suatu proses evaluasi terus-menerus untuk dapat memastikan kualitas penilaian tersebut terjaga mutunya.

Penilaian proses diskusi tutorial dalam PBL diharapkan mendorong mahasiswa untuk belajar aktif secara mandiri (self directed learning) dan mendapatkan pemahaman ilmu yang cukup dalam (deep learning) dan bukan sebaliknya proses penilaian yang dilakukan membuat mahasiswa secara pragmatis mendapatkan nilai sebaik mungkin dan melupakan tujuan digunakannya tutorial sebagai model pembelajaran dalam PBL.

Berdasarkan uraian pada latar belakang di atas, maka diperlukan proses evaluasi apakah bisa menilai secara objektif kemampuan mahasiswa terkait komponen psikometrik, komponen sikap, tanggung jawab, peran aktif dan berkomunikasi, maupun kemampuan kognitif terkait penggunaan sumber informasi, penguasaan informasi dan berpikir kritis. Maka perumusan masalah yang diajukan dalam penelitian ini adalah bagaimana persepsi tutor dan mahasiswa terhadap penilaian proses tutorial yang dijalankan dan bagaimana penilaian tutorial yang direkomendasikan literatur ilmiah.

Penelitian ini memiliki 3 (tujuan) yaitu eksplorasi perspektif tutor dan mahasiswa terhadap penilaian tutorial, eksplorasi literatur ilmiah terkait penilaian proses tutorial PBL, dan merekomendasikan perbaikan sistem penilaian tutorial.

\section{METODE}

Penelitian ini menggunakan metode kualitatif melalui pendekatan studi kasus. Penelitian ini dilakukan di program studi pendidikan dokter fakultas kedokteran Universitas Islam Indonesia. Populasi penelitiannya adalah perwakilan mahasiswa dari angkatan 20112014 dengan variasi jenis kelamin, kemampuan kognitif berdasarkan nilai ujian tulis blok dan variasi keaktifan tutorial berdasarkan rerata nilai keaktifan 
tutorial, dan perwakilan tutor dengan variasi jenis kelamin, alumni/bukan alumni PSPD FK UII, masa kerja, dan pimpinan fakultas/program studi. Pengumpulan data penelitian dilakukan melalui proses FGD dan in-depth interview yang dilakukan oleh peneliti sendiri menggunakan panduan serta direkam dengan audiotape recorder.

\section{HASIL DAN PEMBAHASAN}

\section{Hasil studi literatur}

Tabel rangkuman studi literatur ${ }^{4-19}$ dan persepsi Tutor-Mahasiswa

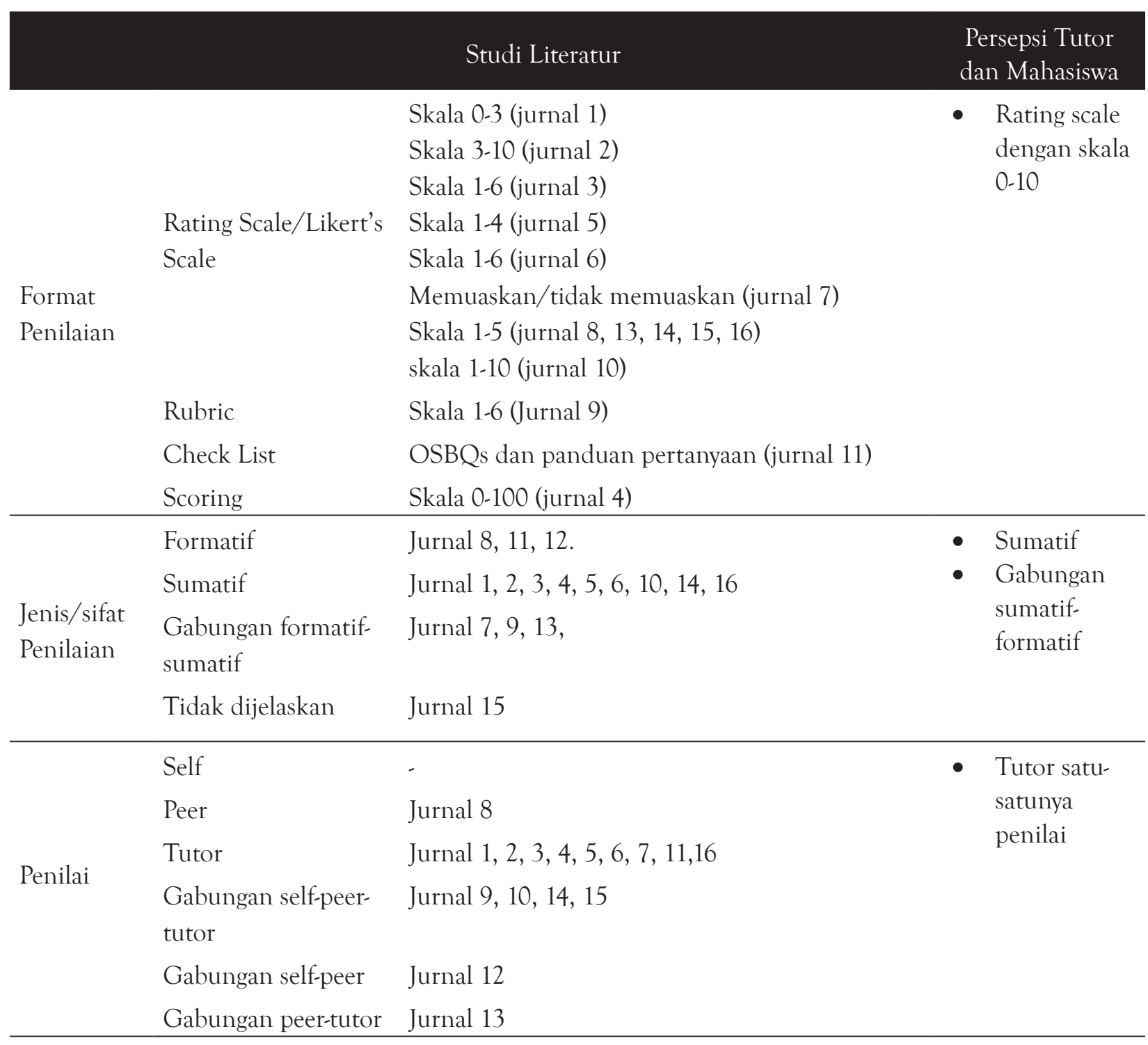




\begin{tabular}{|c|c|c|c|}
\hline $\begin{array}{l}\text { Aspek } \\
\text { Penilaian }\end{array}$ & Dinamika tutorial & $\begin{array}{l}\text { komunikasi (jurnal 1, 2, 12, 15, 16) } \\
\text { kepemimpinan (jurnal 1) } \\
\text { respek/menghargai terhadap kelompok (jurnal 1, } \\
\text { 12, 15) } \\
\text { interaksi kelompok (jurnal 2, 3, 6, 7, 9) } \\
\text { partisipasi aktif (jurnal } 3,12,14,16 \text { ) } \\
\text { personal \& interpersonal (jurnal 4) } \\
\text { kerjasama (jurnal 5, 12, 16) } \\
\text { kolaboratif (jurnal 8) } \\
\text { perilaku \& profesionalisme (jurnal 9) } \\
\text { memberi \& menerima umpan balik (jurnal 10) } \\
\text { tanggung jawab (jurnal 12, 15) } \\
\text { perilaku menanggapi informasi dari orang lain } \\
\text { (jurnal 14) }\end{array}$ & $\begin{array}{l}\text { - aspek kognitif } \\
\text { dan afektif } \\
\text { - kognitif saja } \\
\text { (tidak ada } \\
\text { penilaian } \\
\text { afektif) }\end{array}$ \\
\hline & Kemandirian & $\begin{array}{l}\text { keingintahuan ilmiah (jurnal 1) } \\
\text { autonomi (jurnal 2) } \\
\text { humanism (jurnal 2) } \\
\text { belajar mandiri (jurnal 3, 6, 9, 16) } \\
\text { pengembangan diri (jurnal 5) } \\
\text { motivasi (jurnal 8) } \\
\text { refleksi (jurnal 13) } \\
\text { hasil belajar sesuai tujuan belajar (jurnal 14) } \\
\text { kesadaran diri (jurnal 15) }\end{array}$ & \\
\hline & Kognitif & $\begin{array}{l}\text { efektifitas kelompok (jurnal 1) } \\
\text { penalaran (jurnal 2, 3, 5, 9, 13, 16) } \\
\text { pengetahuan (jurnal 4, 12) } \\
\text { pemecahan masalah (jurnal 4) } \\
\text { analisis (jurnal 4, 7, 12, 14, 15) } \\
\text { kemampuan klinis (jurnal 5) } \\
\text { kemampuan menyampaikan (jurnal 5, 13) } \\
\text { berpikir kritis (jurnal 6, 7) } \\
\text { kognitif (jurnal 8) } \\
\text { aplikasi pengetahuan dasar (jurnal 9) } \\
\text { keputusan (jurnal 9) } \\
\text { penggunaan pengetahuan lampau (jurnal 10, 14) } \\
\text { bertanya, penggunaan pengetahuan baru, } \\
\text { membuat hipotesis, integrasi pengetahuan } \\
\text { terhadap masalah (jurnal 10) } \\
\text { panduan pertanyaan terkait tujuan belajar } \\
\text { (jurnal 11) } \\
\text { identifikasi masalah (jurnal 14) } \\
\text { organisasi informasi (jurnal 14, 15) }\end{array}$ & \\
\hline
\end{tabular}




\section{Studi kualitatif}

Hasil akhir analisis data dari penelitian ini diperoleh 8 (delapan) kategori persepsi tutor dan mahasiswa terhadap penilaian tutorial yang selama ini dilaksanakan di PSPD FK UII. Kedelapan kategori akhir persepsi penilaian tutorial tersebut meliputi:

A. Pengetahuan Tutor dan Mahasiswa terhadap Penilaian Tutorial

Definisi pengetahuan terhadap penilaian penilaian tutorial adalah pengetahuan tutor dan mahasiswa FK UII terkait alat/lembar penilaian tutorial, pelaksanaan penilaian, format penilaian dan hal-hal yang membingungkan/ belum diketahui terkait penilaian tersebut.

1. Alat/lembar penilaian:

a. Bentuk rating scale 0, 1, 2, 3 dengan nilai kumulatif 0-10

b. Aspek penilaian meliputi pengetahuan dan afektif, walaupun masih ada mahasiswa yang tidak mengetahui dan menganggap tiap aspek saling terkait.

"saat ini terus diperhatikan gitu karena ada juga ketika bagus dia ee apa kemampuan dia untuk menyampaikan bagus, dia analisisnya bagus bagus bagus terus wong dia analisisnya sudah bagus koq malah tanggung jawabnya 1 ini kan juga aneh juga gitu lo, jadi yang jenjang itu mestinya diperhatikan sehingga kita bisa menilai dengan sesungguhnya artinya performance dia memang yang kita nilai yang kita berikan itu sesuai dengan apa yang memang dia seharusnya dapat, jadi kalo masukan saya seperti itu" (T3: 2252-2262)

c. Panduan/parameter penilaian sudah ada walaupun interpretasi terhadap panduan tersebut berbeda-beda. Ada tutor yang menganggap panduan tersebut sudah baik dan dapat diikuti namun banyak juga yang menganggap belum baik sehingga melakukan penyesuaian atau modifikasi sendiri. "ada tapi menurut saya pengalaman saya untuk pernilai itu definisi istilahnya definisi operasionalnya kurang jelas gitu, ya misalnya antara 0,1,2,3 itu kurang jelas, contohnya peran aktif ya, misalnya peran aktif memang sudah ada kalo kita mengikuti kurang dari berapa dia nilainya berapa, tapi seberapa aktifnya gitu lo, apakah satu mahasiswa harus menjawab seluruh LO atau harus tanya ee temannya ketika temannya sudah menjelaskan itu nggak nggak jelas kalo saya lo menurut saya"(T7: 372-382).

"tanpa harus dikurangi, nanti ee ini ketuanya bagus mengarahkan diskusi ok, tapi dia nggak pernah he e..nanti nilainya jadi kecil sendiri, muncul, ah yo uwis, itu pengalaman saya"(T6: 568-572).

d. Lembar penilaian yang sama digunakan untuk menilai baik ketua, sekretaris maupun anggota.

"kalo disamakan jelas mereka (ketua Eु sekretaris) akan banyak kedodoran, mereka ya itu tadi hanya akan dinilai tanggung jawabnya, sementara yang lain sudah pasti lewat, jadi ketika mereka jelek, ya mereka jelek, tapi ketika mereka bagus, mereka mungkin belum bisa menyamai kemampuan yang lain" (T5: 615-621).

2. Pelaksanaan penilaian, dilakukan oleh tutor sebagai satu-satunya penilai dan ada standar penilaian namun implementasinya tergantung individu tutor, sedangkan waktu pelaksanaan disetiap pertemuan tutorial dan dilakukan seharusnya saat diskusi sudah selesai.

"penilaian tutor itu dilakukan per pertemuan nanti kemudian di kalkulasikan diakhir" (M15: 90-91)

"sebenarnya saat itu, saat proses diskusi, terakhir saat proses diskusi ditutup ctet nilai itu harus jadi pandangan saya seperti itu karena kalo saya molor satu hari saja memori saya sudah .. ini sing aktif mau sopo, saya banyak menemukan kasus disitu" (T6: 230-235) 
3. Jenis/sifat penilaian, sebagian tutor hanya mengetahui penilaian sumatif (pemberian nilai yang berkontribusi pada nilai akhir) sedangkan penilaian formatif (pemberian feedback) sebagian besar tidak menganggap bagian dari penilaian tutorial yang juga harus diberikan.

"Biasanya ada yang ngasih feedback ada yang ga gitu dok"(M8: 349-350)

B. Persepsi Kesesuaian Penilaian Tutorial dengan Konsep Problem Based Learning (PBL)

Definisi persepsi kesesuaian penilaian tutorial dengan konsep PBL adalah persepsi tutor dan mahasiswa FKUII mengenaikesesuaian penilaian tutorial baik dari segi konsep penilaian, dampak penilain, tools penilaian (format penilaian, aspek penilaian) dengan konsep PBL yang meliputi adult learner (self directed learner, deep learning), constructive, dan collaborative. Persepsi ini terbagi menjadi 2 (dua) yaitu yang menganggap sesuai dan yang menganggap tidak sesuai.

"kemandirian menurut saya kemandirian berpikir kritis dan kolaboratif sama prior knowledge itu menurut saya sudah berusaha di jadikan aspek penilaian oleh FK UII jadi semua itu sudah berusaha dimasukkan dalam penilaian"(M10:666-670)

"kalo tutorial berdasarkan form itu nggak nggak nggak bisa untuk menilai berhasil atau tidaknya diterapkannya PBL itu, kalo menurut saya sih" (T9:1680-1683)

C. Persepsi terhadap Teknis Penilaian

Definisi persepsi terhadap teknis penilaian adalah persepsi tutor dan mahasiswa FK UII terhadap teknis penilaian tutorial yang meliputi teknis pengisian lembar penilaian (cara menilai, cara pengisian, waktu pengisian, dan kesulitan teksnis pengisian) dan teknis pemberian feedback tutorial (inisiatif, waktu dan materi feedback).

"saya tidak pernah melihat apakah tutor ini memberikan penilaian ingat ini si ini tadi sekitar 7 atau berapa gitu jadi bayangan saya beliau malah kayaknya tidak melakukan tadi titik titik atau bintang atau apa tapi beliau, sudah, sudah selesai" (M11: 291-296).

"jadi kalo balik lagi mengenai itu ya, balik lagi kayak diomongin, dulu waktu awal-awal saya jadi tutor itu, karena agak bingung gitu ya baca format penilaiannya saya itu menilainya itu belakangnya dulu, segini dapat segini, nanti baru yang depan itu yang menyesuaikan, yang poin-poin itu menyesuaikan, cuma semakin kesininya, ee saya malah jadi nggak kayak gitu lagi, yaudalah dinilai sesuai aja, kalo misalnya dia pinter, tapi dia jarang noomong, tapi begitu dia ngomong jelas banget saya tetap kasih misalnya poin tanggungjawabnya itu dia 1 misalnya gitu ya, tapi yang 0, 1, 3 nya saya kasih 3, okelah misalnya dia akan sama, sama temannya yang ini Cuma biasanya saya perhatiin lagi nilai, nilai bloknya ini tetap aja lebih bagus jadi saya pikir yaudahlah tutorial inipun hanya berapa persen gitu, saya berusaha menilai sesuai dengan" (T9: 735-743)

"Berbeda ada yang tutor diakhir akhir itu secara sukarela langsung bilang jadi dik yang kurang tu ini ini ini nanti adik ini adik ini besoknya lebih aktif ya kayak gitu, nah tapi ada juga beberapa tutor yang dia itu jenisnya itu maksudnya model nya itu beliau baru mau berkata jika ditanya terlebih dahulu Dok apakah ada yang kurang materinya atau dok bagaimana dengan keaktifannya, boleh minta feedbacknya, baru diutarakan" (M12: 490-499)

D. Penyimpangan Penilaian

Definisi penyimpangan penilaian adalah segala bentuk proses penilaian yang tidak sesuai prosedur dan dapat dipastikan menghasilkan penilaian yang tidak valid. Penyimpangan tersebut meliputi penilai, waktu pelaksanaan penilaian, proses penilaian dan perubahan nilai.

"pada saat itu tutornya keluar jadi yang menilai itu dialihkan ke ketua" (M15: 176-178).

"Kalau pengalaman saya sih dok ada juga dokter itu jadi jam 11 itu udah di nilai udah di tutup ininya jadi memang setelah jam 11 itu ga di titikin lagi" (M6: 306-308). 
"karena ada tutornya yang cuma diam mainan hp gitu kan" (M9: 950-951).

"iya ho o atau atau bahkan ketika nggak nomong sama sekali ya piye carane lah biar ada nilai, soalnya kalo ndak bener-bener nol, itu itu yang yang sekali tetapi ndak sering, sekali dua kali pernah menemukan seperti itu jadikan ya karena masalah sebagainya tetap dikasih nilai" (T5: 1147-1159).

E. Persepsi terhadap Objektifitas Penilaian Definisi persepsi terhadap objektifitas penilaian adalah persepsi tutor dan mahasiswa FK UII terhadap penilaian tutorial yang dilakukan selama ini dalam setiap proses tutorial, yang termasuk objektifitas disini adalah terkait objektifitas nilai yang diberikan oleh tutor terhadap mahasiswa, objektifitas nilai yang diperoleh berdasarkan cara tutor menilai, dan objektifitas nilai berdasarkan performa mahasiswa. Persepsi terhadap objektifitas penilaian ini terbagi ke dalam 2 (dua) kelompok yang menganggap penilaian tutorial selama ini sudah objektif dan yang menganggap penilaian tutorial belum o ya seperti itu karena ada beberapa tutor, tutorial sama dia pasti jelek pasti dipukul rata, saya senang kalo ketemu tutor kayak gitu kayak apa sih ratanya kayak gitu kan, nah jadi selama saya tutorial dan ketemu tutor-tutor kayak gitu mitosnya itu tidak terbukti" (M10: 868-875).

"ada yang ngomong dua kali tapi dia agak lumayan panjang akhirnya saya juga mikir-mikir waduh ini anak prosus dan mungkin dia tadi sudah saya hargai upayanya dia untuk ngomong dua kali la..tadi dan sudah dengan referensi meskipun agak baca-baca akhirnya saya beri 7" (T2: 1376-1382)

F. Dampak Penilaian terhadap Proses Tutorial Definisi dampak penilaian terhadap proses tutorial adalah dampak dari penilaian tutorial terhadap jalannya proses tutorial yang dilakukan oleh mahasiswa maupun yang dilakukan oleh tutor pada saat tutorial berlangsung. Dampak yang ditimbulkan meliputi dampak yang dianggap positif, negatif, tidak berdampak dan dampak negatif jika tutorial tidak dinilai.
"Tutornya juga loh ketika saya tidak menilai saya mesti akan cuma melihat ya ini bagus itu bagus" (T12:822-824)

"adanya penilaian dampak pribadinya ke saya saya mau ga mau seberat apa pun kondisi se sakit apapun saya akan berusaha minimal waktu tutorial itu jangan sampai diem tok atau saya hari ini dapatnya apa pada tutorial pertama tutorial kedua harus dapatnya apa tutorial ketiga harus dapatnya apa" (M7: 11111116)

"Sikap perilaku sikapnya saya, saya jujur cuek, cuek dalam arti saya ga peduli penialaiannya bagaimana" (M6: 131-132)

"ketika tutorial itu tidak dinilai itu kelihatannya akan terjadi ada 2 perpecahan yang pertama mahasiswa itu jadi ya tadi tutorial cuma datang kalo ikut diskusi ya diskusi kalo seumpama ngomong ya ngomong kalo nggak ya nggak kayak gitu tapi ada pecahan satunya lagi itu adalah orang yang memang mengejar pemahaman memang niat awal dia tu pingin paham dan mendalami hal yang secara detail kayak gitu tapi cuma ndak terlalu banyak banyak sih beberapa orang saya rasa" (M12: 933-943)

G. Learning/Educational Impact Penilaian Tutorial Definisi learning/educational impact penilaian tutorial (berkontribusi pada nilai akhir) adalah segala dampak penilaian tutorial beserta semua hal yang terkait (tutor penilai, persentase kontribusi, aspek penilaian) dalam bentuk berbagai macam aktifitas belajar yang dirasakan maupun dilakukan oleh mahasiswa dalam mempersiapkan diri (diluar saat tutorial) menghadapi kegiatan tutorial. Dampak ini bisa dalam bentuk dampak positif, negatif, tidak berdampak bagi mahasiswa dan dampak pembelajaran jika tutorial tidak dinilai.

"performa seseorang di FK UGM dengan disini berbeda, disini itu harus didorong untuk dinilai supaya mereka belajar gitu lo, kalaupun di awal dinilai tutorialnya mau bagaimana paling tidak sedikit-sedikit dirumah mereka sudah membacalah gitu dengan dorongan bahwa tutorial itu dinilai" (T8: 1625-1630) 
"ketika ada kuliah pakar kemudian habis itu ada diskusi tutorial, 50\% bahkan lebih mahasiswa itu mempersiapkan untuk tutorial waktu kuliah pakar itu dok, jadi yang mendengarkan paling banter 30\% lah itupun belum tentu paham" (M16: 814-819)

"kalo menurut saya kembali lagi sih ke diri saya sendiri, saya tu belajar bukan untuk nilai, kalo saya ndak belajar saya mau dapat apa disini, kalo nilai sih kalo bisa dibuat persentasi mungkin itu sekitar 40 \%" (M17: 1253-1257)

"jika tutorial tidak dinilai siapa yang mau belajar gitu kan, pratikum saja bahkan ga lulus ga apa apa orang gak dinilai palingan inhal gitu kan" (M10: 1128-1131)

H. Usulan Penilaian Tutorial

Definisi usulan penilaian tutorial adalah segala usulan terkait penilaian tutorial FK UII kedepan, baik yang diungkapkan secara langsung oleh tutor dan mahasiswa FK UII maupun yang diungkapkan secara tidak langsung seperti kesulitan, kekurangan, ketidaksetujuan terhadap penilaian tutorial yang ada saat ini. Usulan-usulan tersebut yaitu usulan peniadaan/ pelaksanaan penilaian tutorial, perbaikan form penilaian dan panduan, perbaikan aspek-aspek penilaian, dan evaluasi peran tutor dalam penilaian tutorial.

"Tapi nanti kalau budaya kita baik mas ya PBL ini ya udah murni udah pokoknya kamu nanti di uji sudah bisa proses kita percayakan pada dia. Tapi kayaknya kita belum bisa mengawali" (T11: 450-459).

"jadi form penilaian yang baik itu ada perlunya direvisi saya rasa bagaimana si assessor/penilai itu bisa menilai dari depan ke belakang bukan dari belakang kemudian baru di"jlentreh" kedepan" (T5: 164-168).

"mungkin memang perlu di akomodir supaya meminimalisir itu dengan form penilaian yang lebih detil lagi jadi diperjelas lagi yang seperti apasih 0, 1, 2 atau yang 0,1,3 tadi sehingga tidak membuat kita bingung jadi nilainya jadi subyektif gitu"(T10: 450-455) "bentuknya pada saat itu, pada saat itu maksudnya apa dibedakan pertemuan pertama, kedua ketiga" (T11: 665-667)

"sehingga akan lebih bijaksana ketika seorang yang bertugas menjadi seorang ketua atau sekretaris itu parameter nilaiannya berbeda dengan teman-teman lainnya, tidak ditambahkan tapi penilaiannya mungkin berbeda, jadi ada penilaian untuk member, ada penilaian untuk ketua atau sekretaris" (T5: 609-615)

"Penilaiannya seperti yang kita sepakati nilainya, value di UII” (T11723-724)

"saya juga saya rasa saya lebih berat ke positifnya dok dalam artian saya lebih setuju juga dengan tutorial itu dinilai" (M14: 958-960)

"kalo misalnya di UGM tidak dinilai, saya tetep lebih seneng kalo di FK UII dinilai" (T8: 1621 1622)

"saya sebagai pimpinan saya melihat ini penghargaaan mahasiswa terhadap proses tutorial ketika itu tidak kita hargai menurut saya gitu ya walaupun sebenarnya kita juga bermain di persentase itu tidak begitu besar kalau kita secara jujur tidak terlalu besar tapi kita memberikan penghargaan kepada mahasiswa yang berusaha dari hari ke hari. Jadi saya melihat ini justru penting di kita" (T11: 229-237)

"kalo menurut saya mendukung pernyataannya $K$ dituntut ketegasan dalam arti ketegasan buat pimpinan buat menegaskan kepada para tutor supaya dia...nggak-nggak supaya gampangnya, supaya para tutor itu tegas memberi nilai kalo emang dia jelek ya jelek kalo misalnya itu baik.. baik" (M11: 1410-1411)

"kalo gini gimana dok menengahi jadi tetap ada rolling tapi bimbingan tutor dengan jumlah yang nggak terlalu banyak jadi tutornya itu 2 tutor, misalnya saya tutorial 1 dan tutorial 2 nanti skenario 1 saya dengan tutor A tutorial 2 dengan tutor $B$ skenario 2 dengan $B$ yang ini dengan A kalo dengan itu untuk menjembatani 
dengan susahnya apa namanya beradaptasi" (M13: 1653-1661)

"jadi usul kedepannya itu tutor itu dikasih apa namanya untuk mengasih feedback kepada jadi nanti seumpamanya mahasiswanya ada salah satu ketika misalnya saya jadi tutor, BFD turun sebelum jadi ada transparasi nilai itu lo dok diakhir, jadi bagaimana mekanismenya kalo saya terserah tetapi ada ee BFD nilai kamu kurang kalo bisa gini-gini lagi jadi taunya itu sudah dari awal nggak diakhir tiba-tiba nilainya oh nilai saya kurang" (M12: 1746-1758).

Diagram rekomendasi

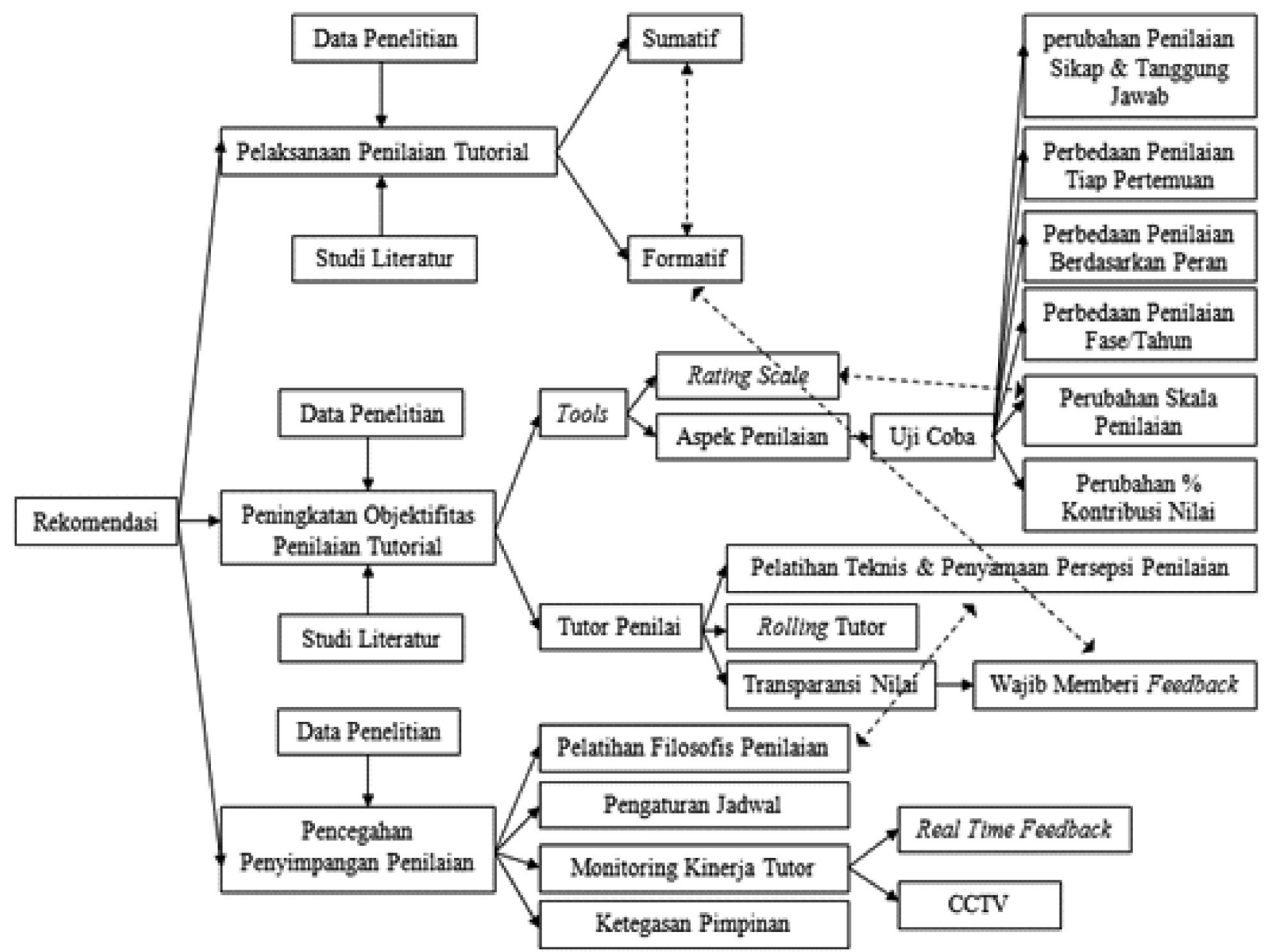

\section{KESIMPULAN}

Studi kasus dalam penelitian ini menghasilkan 8 (delapan) kategori persepsi tutor dan mahasiswa terhadap penilaian tutorial dan rekomendasi perbaikan penilaian tutorial.

Delapan kategori persepsi tersebut:

1. Pengetahuan tutor dan mahasiswa terhadap penilaian tutorial. Tutor dan mahasiswa mengetahui jenis/sifat penilaian tutorial bersifat formatif dan sumatif berbentuk rating scale aspek kognitif dan afektif disertai panduan penilaian. Penilaian dilakukan tutor sebagai satu-satunya penilai. Pengetahuan ini memiliki kesesuaian dengan hasil studi literatur yang peneliti lakukan.

Beberapa hal yang menarik dari kategori ini adalah, tidak semua mahasiswa mengetahui ada 
penilaian afektif, persepsi aspek penilaian tutorial saling berkaitan dan saling mempengaruhi, perbedaan interpretasi panduan penilaian sehingga terjadi penyesuaian/modifikasi kualitas maupun kuantitas tiap aspek penilaian, lembar penilaian (aspek penilaian) yang sama untuk menilai peran yang berbeda dan pertemuan yang berbeda (tutorial I, II, III), serta tidak semua tutor memberikan feedback kepada mahasiswa.

2. Persepsi kesesuaian penilaian tutorial dengan konsep PBL. Aspek-aspek penilaian sesuai dengan konsep PBL yang menekankan adult learner (self directed learner dan deep learning), constructive dan collaborative, namun implementasinya masih banyak penyimpangan konsep PBL. Meskipun mengetahui konsep PBL tutorial tidak memerlukan penilaian sumatif namun penilaian tutorial masih dibutuhkan untuk mendorong (eksternal motivasi) proses pembentukan budaya/konsep PBL pada mahasiswa.

3. Persepsi terhadap teknis penilaian. Pertama, variasi penilaian (sumatif) antar tutor meliputi cara menilai, mengisi lembar penilaian dan waktu pengisian. Kedua, variasi teknis pemberian feedback (formatif) dari segi inisiatif pemberian, saat pemberian dan materi feedback yang diberikan.

4. Penyimpangan penilaian. Empat penyimpangan penilaian yang terjadi yaitu tidak dilakukan sendiri oleh tutor, waktu pelaksanaan penilaian tidak sesaat setelah tutorial selesai, proses penilaian tidak melalui pengamatan utuh sepanjang tutorial, dan pengubahan nilai oleh tutor.

5. Persepsi terhadap objektifitas penilaian. Ada dua kelompok yaitu sudah objektif dan belum/ tidak objektif. Secara kuantitatif lebih banyak persepsi belum/tidak objektif, meskipun demikian ketidaksesuaian nilai tutorial dengan performa mahasiswa hanya terjadi pada kasuskasus tertentu/khusus.

6. Dampak penilaian terhadap proses tutorial. Ada 3 (tiga) kelompok, pertama positif sebagai motivasi eksternal menyebabkan tutor serius mencermati proses tutorial dan bagi mahasiswa menciptakan kondisi untuk selalu aktif dalam tutorial. Kedua, negatif menyebabkan terjadinya penyimpangan penilaian yang dilakukan tutor sedangkan bagi mahasiswa menimbulkan sikap pragmatis terhadap nilai tutorial. Ketiga, tidak berdampak terhadap keaktifan mahasiswa dengan karakter pembelajar dewasa dan kepada mahasiswa yang acuh-tak acuh/tidak peduli tutorial. Persepsi tutor dan mahasiswa terhadap wacana tutorial tidak dinilai (sumatif) yaitu membuat mahasiswa malas mengikuti tutorial dan menurunkan kualitas tutorial.

7. Learning/educational impact penilaian tutorial. Ada 3 (tiga) kelompok yaitu pertama, sebagian besar berdampak positif berupa motivasi eksternal belajar mempersiapkan diri menghadapi tutorial dan alat evaluasi pencapaian materi. Kedua, dampak negatif sikap pragmatis yaitu mempelajari apa (materi maupun proses) yang dinilai dan superfisial (menghafal). Ketiga, tidak memberikan dampak pembelajaran kepada 2 (karakter) mahasiswa yaitu karakter pembelajar dewasa dan yang acuhtak acuh/tidak peduli/tidak memiliki motivasi belajar. Persepsi terhadap wacana tutorial tidak dinilai akan menurunkan motivasi belajar sebagian besar mahasiswa.

8. Usulan penilaian tutorial. Tutor dan mahasiswa sepakat penilaian tutorial masih sangat dibutuhkan (belum saatnya untuk tidak dinilai). Perlu perbaikan penilaian terkait bentuk lembar penilaian, panduan penilaian, dan aspek-aspek penilaian, serta optimalisasi pemberian feedback kepada mahasiswa baik dari segi materi (termasuk feedback terkait value perilaku) maupun waktu/ cara pemberian feedback. Upaya meminimalkan subjektifitas dan perbedaan persepsi antar tutor berupa rolling tutor, optimalisasi buku monitoring proses tutorial, transparansi nilai tutorial, dan optimalisasi pemanfaatan CCTV.

Berdasarkan 8 (delapan) kesimpulan persepsi di atas, perbaikan penilaian tutorial yang direkomendasikan yaitu:

1. Pelaksanaan penilaian tutorial yang direkomendasikan untuk terus dilakukan. 
2. Rekomendasi mengenai upaya peningkatan objektifitas penilaian tutorial.

3. Rekomendasi mengenai upaya pencegahan penyimpangan penilaian

\section{SARAN}

Berdasarkan hasil penelitian ini variasi persepsi yang diperoleh sudah teridentifikasi dalam teori-teori studi literatur yang peneliti lakukan Permasalahan yang muncul kemudian adalah masing-masing institusi pendidikan kedokteran memiliki keunikan tersendiri terkait dengan kultur dan sumber daya yang ada. Implementasi suatu metode penilaian harus bisa memadukan antara teori dan keunikan disetiap institusi pendidikan tersebut. Oleh karena itu saran dari penelitian ini yaitu:

1. Perlu dilakukan penelitian lebih lanjut yang bersifat action research penilaian tutorial baru sesuai dengan hasil rekomendasi penelitian ini.

2. Keputusan pemilihan suatu metode penilaian tutorial yang tepat diimplementasikan pada suatu institusi harus memperhatikan dan menggabungkan setidaknya 3 (tiga) hal yaitu, pertama pertimbangan perlu tidaknya penilaian tutorial dilakukan dengan memperhatikan tujuan, keuntungan dan kerugian penilaian tersebut. Kedua, masing-masing institusi pendidikan kedokteran memiliki keunikan tersendiri terkait dengan kultur dan sumber daya yang ada sehingga perlu mempertimbangkan masukan tutor dan mahasiswa sebagai pihak yang menilai maupun dinilai serta masukan dari pimpinan institusi sebagai pihak yang mewakili kepentingan institusi pendidikan. Ketiga, studi literatur untuk mencari teori-teori atau metode penilaian tutorial terbaik dengan bukti ilmiah yang dapat dipertanggungjawabkan.

\section{UCAPAN TERIMA KASIH}

Peneliti mengucapkan terima kasih kepada dr. Gandes Retno Rahayu, M.Med.Ed, Ph.D dan dr. Efrayim Suryadi, SU, PA (K) MHPE., yang memberikan banyak masukan dan dukungan pada penelitian ini.

\section{DAFTAR PUSTAKA}

1. Dornan T, Mann KV, Scherpbier AJ, Spencer JA. Medical education: theory and practice. Elsevier Health Sciences; 2011.

2. Nitko AJ, Educational Assessment of Students $2^{\text {nd }}$ ed., Merril an Imprint of Prantice Hall; 1996.

3. Duffield KE, Spencer JA. A survey of medical students' views about the purposes and fairness of assessment. Medical education, $2^{\text {nd }}$ ed. 2002; 36(9), 879-86.

4. Hebert R, Bravo G. Development and validation of an evaluation instrument for medical students in tutorials. Academic Medicine, 1996; 71(5), 488-94.

5. Des Marchais JE, Vu NV. Developing and evaluating the student assessment system in the preclinical problem-based curriculum at Sherbrooke. Academic Medicine, 1996; 71(3), 274-83.

6. Valle R, Petra L, Martínez Gonzáez A, Rojas Ramirez JA, Morales Lopez S, Piña Garza B. Assessment of student performance in problem based learning tutorial sessions. Medical Education, 1999; 33(11), 818-22.

7. Allareddy V, Havens AM, Howell TH, Karimbux NY. Evaluation of a new assessment tool in problembased learning tutorials in dental education. Journal of dental education, 2011; 75(5), 665-71.

8. St-Onge C, Frenette E, Côté DJ, De Champlain A. Multiple tutorial-based assessments: a generalizability study. BMC medical education, 2014; 14(1), 30.

9. Ladouceur MG, Rideout EM, Black ME, Crooks DL, O'Mara LM, Schmuck ML. Development of an instrument to assess individual student performance in small group tutorials. The Journal of nursing education, 2004; 43(10), 447-55.

10. Zimitat C, Miflin B. Using assessment to induct students and staff into the PBL tutorial process. Assessment $\mathcal{E}$ Evaluation in Higher Education, 2003; 28(1), 17-32.

11. Kamp RJ, Dolmans DH, Van Berkel HJ, Schmidt HG. The effect of midterm peer feedback on student functioning in problem-based tutorials. Advances in Health Sciences Education, 2013; 18(2), 199-213.

12. Elizondo-Montemayor LL. Formative and summative assessment of the Problem-Based Learning tutorial session using a criterion-referenced system. The Journal of the International Association of Medical Science Educators, 2004; 14, 8-14. 
13. Bollela VR, Gabarra MH, da Costa C, Lima RC. Students and tutors' social representations of assessment in problem-based learning tutorials supporting change. BMC medical education, 2009; 9(1), 30.

14. AlHoqail IA, Badr FM. Objective structured brainstorming questions (OSBQs) in PBL tutorial sessions: Evidence based pilot study.International journal of health sciences, 2010; 4(2), 93.

15. Reiter HI, Eva KW, Hatala RM, Norman GR. Self and peer assessment in tutorials: application of a relative-ranking model. Academic Medicine, 2002; 77(11), 1134-9.

16. Kritikos VS, Woulfe J, Sukkar MB, Saini B. Intergroup peer assessment in problem-based learning tutorials for undergraduate pharmacy students. American journal of pharmaceutical education, 2011; 75(4).

17. Machado JL, Machado VM, Grec W, Bollela VR, Vieira JE. Self-and peer assessment may not be an accurate measure of PBL tutorial process. BMC medical education, 2008; 8(1):55.

18. Papinczak T, Young L, Groves M, Haynes M. An analysis of peer, self, and tutor assessment in problembased learning tutorials. Medical Teacher, 2007; 29(5):122-32.

19. Tan CP, Tan NH. A simple instrument for the assessment of student performance in problem-based learning tutorials. Ann Acad Med Singapore, 2006; 35, 634-41. 